\title{
Long-term trends in estuarine nutrients and chlorophyll, and short-term effects of variation in watershed discharge
}

\author{
Thomas E. Jordan, David L. Correll, Joseph Miklas, Donald E. Weller
}

Smithsonian Environmental Research Center, Edgewater, Maryland 21037, USA

\begin{abstract}
For up to 18 yr we monitored salinity and the concentrations of nutrients, organic matter, plant pigments, and suspended particles in the Rhode River (a subestuary of Chesapeake Bay, USA) to examine long-term trends and relationships to watershed discharges. There was no clear evidence of increasing eutrophication. Chlorophyll concentration did not show a long-term trend, although pheopigments increased. Total suspended particles and forms of $P, N$, and $C$ showed either a decrease or no trend, except for dissolved ammonium, which increased slightly in one segment of the estuary. The largest and most consistent trend was a decrease in dissolved organic $\mathrm{N}$. We also analyzed correlations between watershed flow and concentrations at weekly and seasonal time scales, resolving the different influences of the Susquehanna River and local watersheds. In some cases, nitrate was positively correlated with either local or Susquehanna flow depending on season, location in the estuary, and time scale. At both weekly and seasonal time scales, chlorophyll was positively correlated with Susquehanna flow in spring in one segment of the estuary. At the seasonal time scale, chlorophyll in summer was correlated with Susquehanna flow of the previous spring. These results and the pattern of fluctuation in the ratio of dissolved inorganic N:P support the hypothesis that chlorophyll concentrations in spring are controlled by nitrate inputs from the Susquehanna, while in summer they are controlled by the regeneration of inorganic $\mathrm{N}$ from organic matter produced in the spring.
\end{abstract}

\section{INTRODUCTION}

Fluctuations in watershed discharge alter the influx of nutrients into estuaries and may in turn affect phytoplankton standing stocks. Exogenous nutrient inputs can have a fertilizing effect either immediately or after a time lag. For example, the amount of nitrate input from the Susquehanna River during spring has been linked to the intensity of spring blooms and subsequent summer productivity in the mesohaline reach of Chesapeake Bay, USA (Malone et al. 1988). Similarly, annual riverine input of $N$ (but not $P$ ) is correlated with peak production and chlorophyll concentrations in central Chesapeake Bay (Boynton et al. 1982).

Watershed discharges and estuarine responses can fluctuate at a variety of time scales. For example, over a few days, individual rain events induce short-lived pulses of watershed discharge and correspondingly short-lived effects in the estuary. However, changes in the frequency of rain events may produce effects over months or even years. In addition, temperate estuaries respond to regular seasonal fluctuations in watershed discharges caused by the annual cycle of evapotranspiration.

Over decades, increasing anthropogenic inputs of nutrients cause eutrophication (e.g. Carpenter et al. 1969, Jaworski 1981), which can dramatically increase estuarine phytoplankton production and biomass (e.g. Brush 1984). Officer et al. (1984) suggest that nutrient enrichment of Chesapeake Bay has led to increasing phytoplankton production and consequent decreases in the dissolved oxygen content of bottom waters, with potentially devastating impacts on macrofauna. Increases in phytoplankton standing stocks in Chesapeake Bay and its tributaries may have also contributed to the widespread decline of submerged aquatic vegetation in the early 1970 s (Kemp et al. 1983) and striped bass in the 1980s (Price et al. 1985).

Detecting eutrophication against the background of fluctuating freshwater inflow can be difficult (D'Elia 1982), but natural short-term variations of watershed inputs provide an opportunity to observe the influence 
of the watershed on the estuary. Responses to natural variations in nutrient inputs may provide evidence of nutrient limitation at the ecosystem level. Such evidence has been lacking due to the impracticality of experimental manipulations of whole estuaries (Hecky \& Kilham 1988) and the difficulties of analyzing natural variation. When analyzing natural variation, long-term data are essential to resolve the different scales of temporal variability, and care must be taken to isolate statistically sources of variation at different time scales. Unfortunately, there have been few studies long enough to accomplish this.

Since the early 1970 s we have studied the flow of N and $P$ through the Rhode River, a subestuary of Chesapeake Bay, and its watershed (e.g. Jordan et al 1986). The Rhode River is influenced both by its local watershed and by remote watersheds which drain into the upper Chesapeake Bay mostly via the Susquehanna River. In this paper, we analyze long-term trends in the Rhode River estuary based on weekly measurements of chlorophyll concentrations spanning $11 \mathrm{yr}$ and nutrient concentrations spanning up to $18 \mathrm{yr}$. We also examine the linkage between the watersheds and estuary as revealed by correlations of watershed discharges with chlorophyll and nutrient concentrations in the estuary, and we evaluate the relative influence of remote and local watersheds at weekly and seasonal time scales. Variations in watershed discharge provide a natural whole-ecosystem experiment to test the hypothesis that high watershed discharge leads to increases in phytoplankton biomass due to the increased supply of allochthonous nutrients.

\section{METHODS}

Study site. The Rhode River estuary $\left(38^{\circ} 51^{\prime} \mathrm{N}\right.$, $75^{\circ} 36^{\prime} \mathrm{W}$; Fig. 1) is one of several tributary embayments or subestuaries on the western shore of Chesapeake Bay. It is $550 \mathrm{ha}$ in area and averages $2 \mathrm{~m}$ deep with a maximum depth of $4 \mathrm{~m}$. The mean tidal range is $30 \mathrm{~cm}$, but weather conditions often cause more extreme changes in water level. Salinity varies seasonally from 0 ppt at the head of the estuary in spring to almost 20 ppt at the mouth in fall during years with low runoff. Mixing processes in the lower Rhode River are driven by changes in salinity in Chesapeake Bay (Han 1974), as in many subestuaries of Chesapeake Bay (Schubel \& Pritchard 1986), but the waters of the upper Rhode River, where we concentrated our study, are measurably diluted by runoff from the local watershed. The 2300 ha watershed of the upper estuary is $62 \%$ forest, $23 \%$ croplands, $12 \%$ pasture, and $3 \%$ freshwater swamp (Correll 1977). The croplands are the source of most of the nitrogen and phosphorus discharged from the local watershed (Jordan et al. 1986).

Sampling and analysis. For sampling purposes we divided the estuary into 8 segments (Fig. 1). In this paper we focus on Segments 4 and 5 because we have more data for these segments than for Segments 1 to 3, and because they are influenced by the local watershed but are not completely flushed by high runoff as are Segments 6 to 8 . We began sampling in 1971, but our most intensive sampling was in the 1980 s (Table 1). During the 1980 s and in 1978 we took spa-

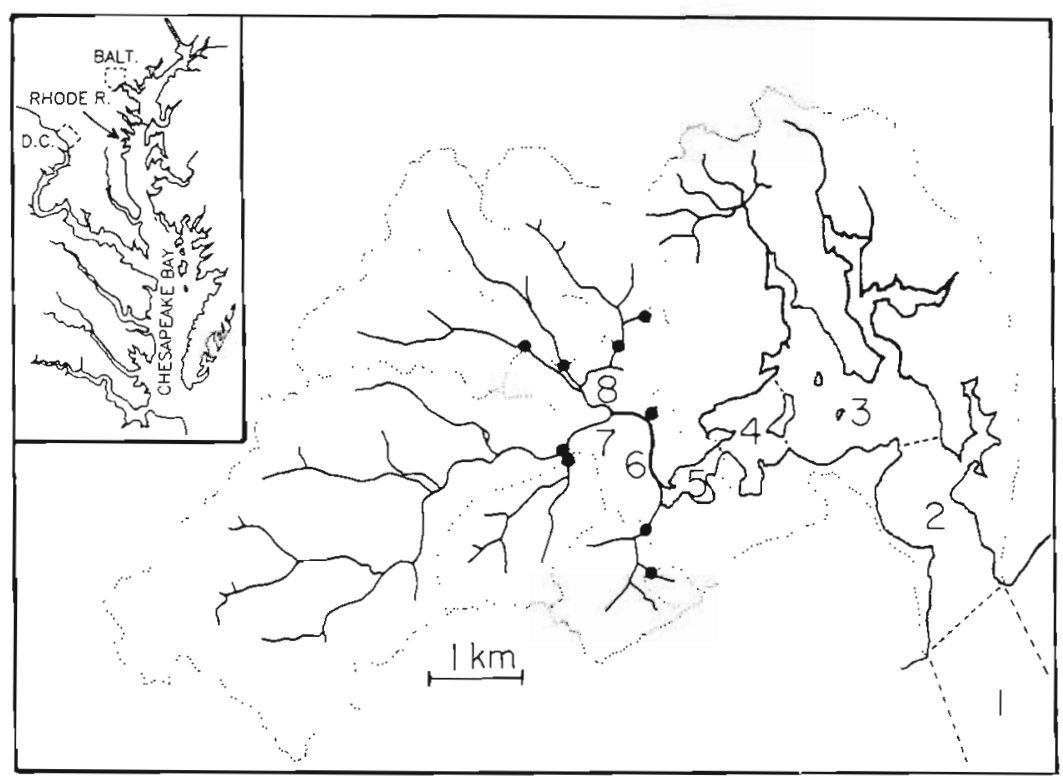

Fig. 1. The Rhode River, USA, and its watershed. The river was divided into numbered segments for sampling. Dotted lines indicate sub-watersheds. (•) Automated watershed monitoring stations. Inset: location of Rhode River near the cities of Washington, D.C., and Baltimore, Maryland 
Table 1. Years in which constituents were monitored in the Rhode River estuary, USA

\begin{tabular}{|lcc|}
\hline Constituent & Abbreviation & Years sampled \\
\hline Chloride & $\mathrm{Cl}$ & $1971-76,1978,1980-87$ \\
Dissolved phosphate & $\mathrm{DPO}_{4}$ & $1971-76,1978,1980-88$ \\
Particulate phosphate & $\mathrm{PPO}_{4}$ & $1971-76,1978,1980-88$ \\
Dissolved organic phosphorus & $\mathrm{DOP}$ & $1974-76,1978,1980-88$ \\
Particulate organic phosphorus & $\mathrm{POP}$ & $1974-76,1978,1980-88$ \\
Dissolved ammonium & $\mathrm{DNH}_{4}$ & $1972-76,1978,1980-88$ \\
Particulate ammonium & $\mathrm{PNH}_{4}$ & $1980-88$ \\
Nitrate plus nitrite & $\mathrm{NO}_{3}$ & $1972-76,1978,1980-88$ \\
Dissolved organic nitrogen & $\mathrm{DON}$ & $1980-88$ \\
Particulate organic nitrogen & $\mathrm{PON}$ & $1980-88$ \\
Dissolved organic carbon & $\mathrm{DOC}$ & $1980-88$ \\
Particulate organic carbon & $\mathrm{POC}$ & $1980-88$ \\
Chlorophyll a & $\mathrm{Chl}$ & $1978,1980-89$ \\
Pheopigments & $\mathrm{Pheo}$ & $1980-89$ \\
Total suspended particles & $\mathrm{TSP}$ & $1980-87$ \\
\hline
\end{tabular}

tially integrated samples by continuously pumping surface water while cruising the lengths of the segments of the estuary. From 1971 through 1976, we sampled at the boundaries and centers of the segments (Fig. 1). We averaged concentrations by segment for the 1971-1976 samples for comparison with the later spatially integrated samples. Sampling was generally from March to November, but some samples were taken in winter in the early 1970s. Samples were usually taken weekly, but were taken every other week after 1986. Abbreviations for sampled constituents are given in Table 1.

The following techniques were used for analysis of $\mathrm{N}$ and $P$ species. Samples to be analyzed for dissolved substances were filtered with prewashed $0.45 \mu \mathrm{m}$ Millipore filters. Total $\mathrm{P}$ in filtered and unfiltered samples was digested to phosphate with perchloric acid (King 1932). Phosphate in the digestate and $\mathrm{DPO}_{4}$ in filtered samples were analyzed by reaction with stannous chloride and ammonium molybdate (APHA 1976). Internal standards were used to correct phosphate concentrations for chloride interference. Total Kjeldhal N was digested with sulfuric acid, Hengar granules and hydrogen peroxide (Martin 1972). The resultant ammonia was distilled and analyzed by Nesslerization (APHA 1976). $\mathrm{DNH}_{4}$ was oxidized to nitrite by alkaline hypochlorite (Strickland \& Parsons 1972). Dissolved $\mathrm{NO}_{3}$ was reduced to nitrite by cadmium amalgam, and nitrite was analyzed by reaction with sulfanilamide (APHA 1976). Phosphate and ammonium bound to particles were extracted by collecting particles on $0.4 \mu \mathrm{m}$ Nuclepore filters, and then rinsing with $1 \mathrm{M} \mathrm{KCl}$ (Keeney \& Nelson 1982) to extract $\mathrm{PNH}_{4}$, or with $0.5 \mathrm{~N}$ $\mathrm{H}_{2} \mathrm{SO}_{4}$ (Correll \& Miklas 1975) to extract $\mathrm{PPO}_{4}$

From results of the above analyses we calculated PON and POP, and DON and DOP. PON was calcu- lated by subtracting Kjeldhal $\mathrm{N}$ in filtered samples and $\mathrm{PNH}_{4}$ from Kjeldhal $\mathrm{N}$ in unfiltered samples. Similarly, POP was calculated by subtracting the total $\mathrm{P}$ in filtered samples and $\mathrm{PPO}_{4}$ from total $\mathrm{P}$ in unfiltered samples. DON was calculated by subtracting $\mathrm{DNH}_{4}$ from Kjeldhal $\mathrm{N}$ in filtered samples. Likewise, DOP was calculated by subtracting $\mathrm{DPO}_{4}$ from total $\mathrm{P}$ in filtered samples.

Prior to $1983 \mathrm{DOC}$ and POC were analyzed by drying samples at $60^{\circ} \mathrm{C}$, followed by reaction with potassium dichromate in $67 \%$ sulfuric acid at $100^{\circ} \mathrm{C}$ for $3 \mathrm{~h}$ (Maciolek 1962) with $\mathrm{HgSO}_{4}$ added to complex halides (Dobbs \& Williams 1963). Organic carbon was calculated from the amount of unreacted dichromate measured colorimetrically (Maciolek 1962, Gandy \& Ramanathan 1964). After 1983 organic carbon was analyzed by persulfate digestion in sealed ampules (Strickland \& Parsons 1972) and measurement of the resulting $\mathrm{CO}_{2}$ with a Coulometric carbon analyzer (Huffman 1977). For 4 years we used both methods for measuring organic carbon to ensure their comparability. Results of both methods did not differ systematically, but the persulfate method was slightly more precise.

Chlorophylls, pheopigments, and carotenoids were measured spectrophotometrically (Strickland \& Parsons 1972, Jeffrey \& Humphrey 1975) after collecting particles on Schleicher \& Schuell glass fiber filters, macerating the filters, and extracting the pigments with a mixture of acetone and DMSO (Shoaf \& Lium 1976). Cl was measured directly with a Dionex model 16 ion chromatograph until 1986, when it was measured with a Technicon Autoanalyzer (Technicon 1978, 1983). Both $\mathrm{Cl}$ analysis techniques were routinely standardized against the same standard seawater sample to 
ensure that they did not yield systematically different results. TSP was measured by filtering through prewashed, pre-weighed $0.4 \mu \mathrm{m}$ filters, rinsing with distilled water to remove salts, drying, and re-weighing.

Since 1974, we have monitored water discharges from up to $90 \%$ of the watershed of the upper Rhode River with a network of automated samplers (Fig. 1; Correll 1977, 1981a, Jordan et al. 1986). Data on Susquehanna River flow at Conowingo Dam at the head of Chesapeake Bay was obtained from the US Geological Survey.

Statistical analysis. We analyzed long-term trends in concentrations and fluctuations in concentrations at time scales of weeks or several months. Long-term trends were tested with the nonparametric, seasonal Kendall's $\tau$ which tests for long-term trends and differences in trends among different weeks of the year (van Belle \& Hughes 1984). We used the method of Hirsch et al. (1982) to calculate the median rates of long-term changes that were statistically significant.

Analysis of correlations between watershed discharges and nutrient and chlorophyll concentrations was complicated by non-normal distributions, seasonality, long-term trends, and serial correlation. We will illustrate our approach to these problems using the data on Susquehanna flow at Conowingo Dam. The raw data are not normally distributed - there are relatively few occurrences of very high values, and variance is highest when flows are highest (Fig. 2). We used the Box-Cox method (Sokal \& Rohlf 1981) to identify the best power transformation for normalizing the data (in this case, a log transformation; Fig. 2). Some variables, such as $\mathrm{NO}_{3}$ and pheopigment concentrations, were occasionally equal to zero or below the detection limits of our analytical techniques. Zero values cannot be power-transformed, so we added a constant equal to the smallest observed non-zero value to all our observations before transformation (Sokal \& Rohlf 1981).

To analyze the correlations of estuarine chemistry with watershed discharge, it was necessary to remove seasonal fluctuations from our data. Otherwise, correlations of variables that have regular seasonal fluctuations would simply reflect the correspondence or lack of correspondence of their seasonality. Therefore, we deseasonalized the transformed data by subtracting from the individual weekly measurements the mean for the corresponding week of the year based on data from all of the years (e.g. Fig. 2). Likewise, it was necessary to remove long-term trends in variables before correlations were tested (Box \& Jenkins 1976). Therefore, we tested the deseasonalized data for trends (van Belle \& Hughes 1984), calculated the rates of long-term change of the significant trends (Hirsch et al. 1982), and used these rates to detrend the data. We also removed data
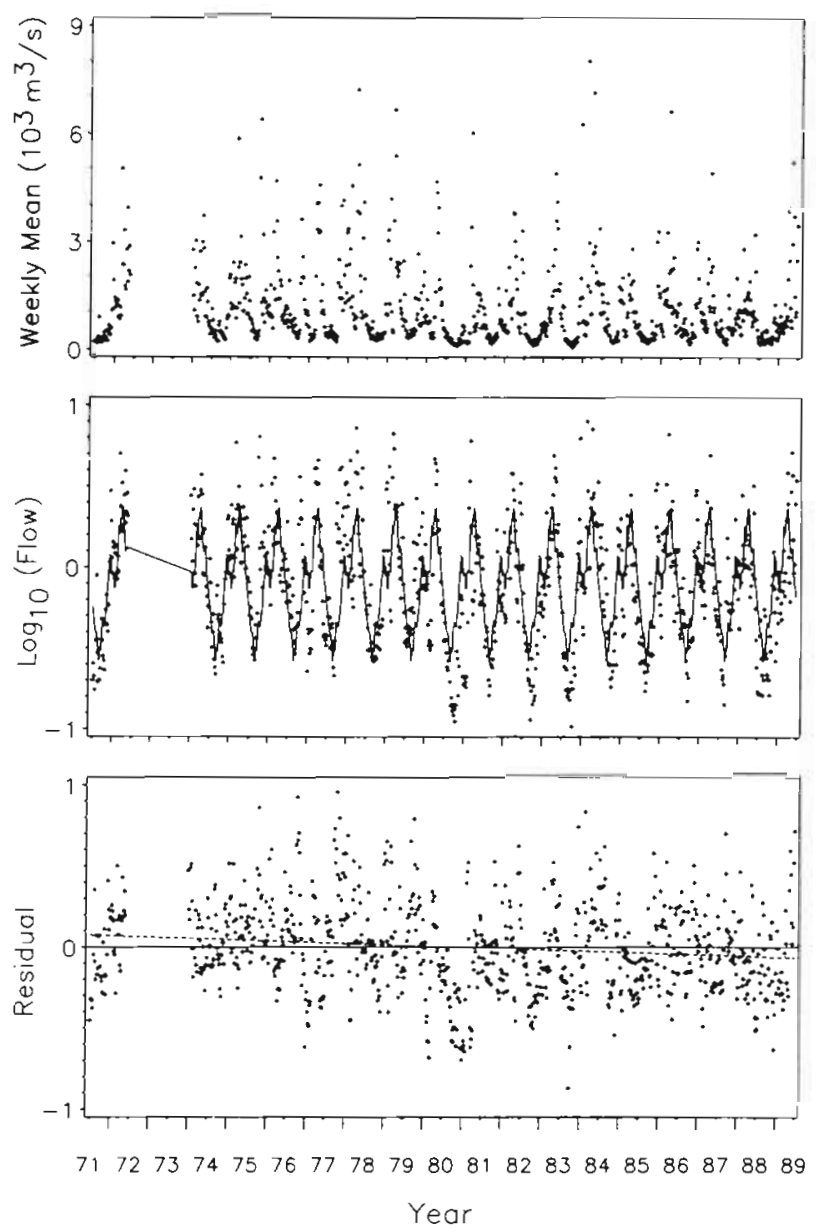

Fig. 2. (Top) Weekly mean flow rate of Susquehanna River at Conowingo Dam, 1971 to 1989. (Middle) Logarithm of flow rate. Line connects mean flow rate for each week of the year based on all years of data. (Bottom) Deseasonalized residuals, i.e., the differences between the points and the line in the middle panel. The dashed line is determined from the slope of the long-term trend of the desasonalized residuals (Hirsch et al. 1982). The differences between the points and the dashed line are the detrended, deseasonalized residuals

from 1972 after tropical storm Agnes caused extremely high Susquehanna flow, because we did not want our analyses to be dominated by this one very unusual event. We also omitted 1973 data as a precaution against possible lingering effects of this storm (see Boynton et al. 1982)

Another problem was that most of our data were serially correlated, that is, measurements were correlated with preceding measurements (e.g. Fig. 3). Testing for correlations between 2 sets of serially correlated data would result in an exaggerated impression of statistical power since the sequential data are not independent measurements. It would be pseudoreplication in time (sensu Hurlburt 1984). Therefore, we removed serial correlation by 'prewhitening' the data using autoregressive integrated moving average (ARIMA) 

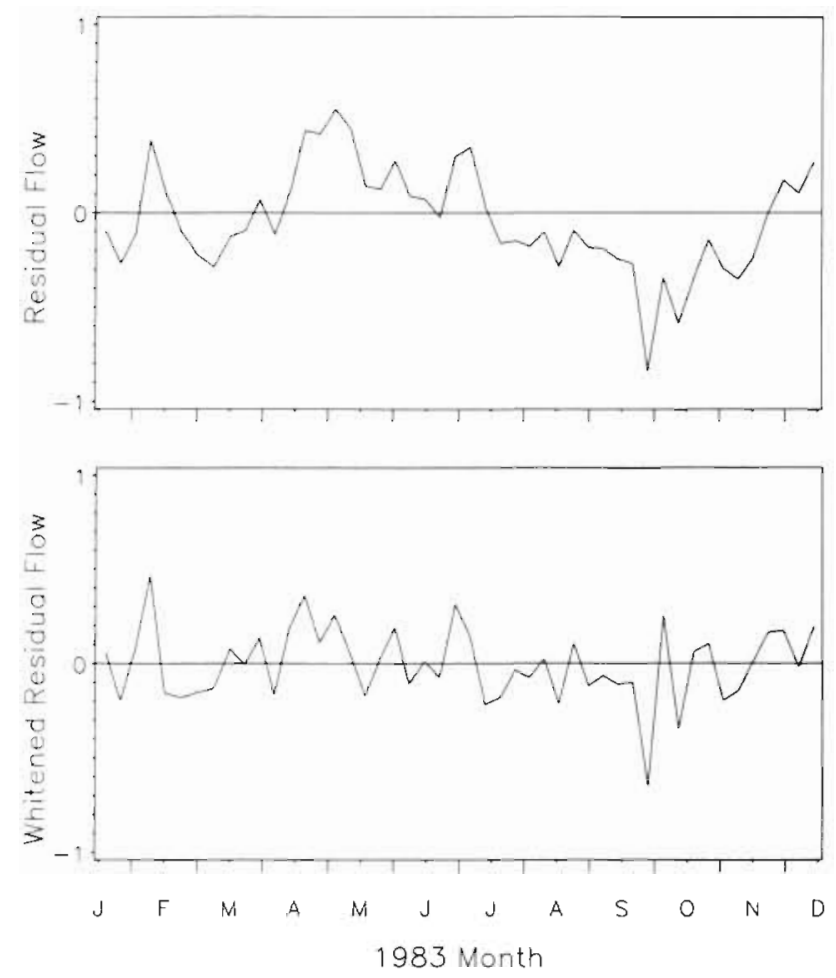

Fig. 3. (Top) Detrended, deseasonalized residuals of Susquehanna River flow for 1983. (Bottom) Detrended, deseasonalized residuals whitened using an autoregressive timeseries model to remove serial correlation. In both cases residuals are dimensionless

models (Box \& Jenkins 1976, SAS Institute Inc, 1984), as done by Goldman et al. (1989) in analyzing correlations of weather with primary production in lakes. The ARIMA model is used to forecast the value of a data point based on the values of preceding data points. The difference between the forecast value and the actual value is the whitened residual. This residual reflects the degree to which a measurement departs from the previous pattern of measurements. The term 'whitened' originates from the expression 'white noise' given to time series of values which do not fluctuate at any regular frequency. Analogously, white light is made up of light of all frequencies (colors) mixed equally.

Prewhitening the nutrient and chlorophyll data was complicated by gaps in the time series primarily due to lack of winter measurements. To whiten a data set containing gaps, we selected all data runs of at least 7 consecutive weekly measurements, assembled these into a single data set with different runs linked by 3 consecutive zero values, and then fitted the ARIMA whitening model. Because of the interruptions in the time series, we selected models of first to third order. We confirmed that autoregressive parameters were very robust to gaps by taking time series that lacked gaps and deleting data to simulate the effect of gaps.
We avoided moving average parameters, since we found that these were not robust to gaps. Analysis of residuals showed that our models removed serial correlation from the data whether or not gaps were present.

Our procedures produced sets of normally distributed data lacking seasonal and long-term trends, in which each measurement is independent of the preceding measurements (e.g. Fig. 3). These data are measurements of the weekly fluctuations away from the seasonal mean, the long-term trend, and the preceding measurements. Therefore, correlation analysis of these data focuses specifically on variations at the weekly time scale. By removing serial correlation, we also increase our ability to detect time lags in correlations of variables. Correlations at the seasonal time scale were analyzed by aggregating the normalized, deseasonalized, detrended data, by first averaging 4 wk periods (roughly monthly) and then $12 \mathrm{wk}$ seasons.

\section{RESULTS}

\section{Long-term trends}

Several constituents showed statistically significant ( $p<0.05$, Kendall's $\tau$, van Belle \& Hughes 1984) longterm trends (Table 2). Total suspended particles and

Table 2. Long-term trends in concentrations of constituents in the Rhode River extuary. Only data for significant trends are given $(p<0.05$, Kendall's $r$, van Belle \& Hughes 1984) Change per decade is based on median rate (Hirsch et al 1982). Units are: $\mathrm{N}$ and $\mathrm{P}$ species, $\mu \mathrm{mol} \mathrm{N}$ or $\mathrm{P} \mathrm{I}^{-1} ; \mathrm{Cl}, \mathrm{mmol}$ $1^{-1}$; TSP, $\mathrm{mg} \mathrm{l}^{-1}$; Chl a and Pheo, $\mu \mathrm{g} \mathrm{l}^{-1}$ Percent change per decade is relative to the mean concentration. Seg.: Segment; abbreviations for constituents are given in Table 1

\begin{tabular}{|c|c|c|c|c|}
\hline \multirow{2}{*}{$\begin{array}{l}\text { Con- } \\
\text { stituent }\end{array}$} & \multicolumn{2}{|c|}{ Change decade $e^{-1}$} & \multicolumn{2}{|c|}{$\%$ Change decade ${ }^{-1}$} \\
\hline & $\begin{array}{c}\text { Seg. } \\
4\end{array}$ & $\begin{array}{c}\text { Seg. } \\
5\end{array}$ & $\begin{array}{c}\text { Seg. } \\
4\end{array}$ & $\begin{array}{c}\text { Seg. } \\
5\end{array}$ \\
\hline $\mathrm{Cl}$ & 46 & 58 & 31 & 48 \\
\hline $\mathrm{DPO}_{4}$ & -0.097 & - & -18 & - \\
\hline $\mathrm{PPO}_{4}$ & -0.14 & -0.58 & -25 & -37 \\
\hline DOP & -0.17 & -0.16 & -19 & -16 \\
\hline $\mathrm{POP}$ & -0.58 & - & -20 & - \\
\hline $\mathrm{DNH}_{4}$ & 0.58 & - & -17 & - \\
\hline $\mathrm{PNH}_{4}$ & - & - & - & - \\
\hline $\mathrm{NO}_{3}$ & - & -0.24 & - & -6.2 \\
\hline $\mathrm{DON}^{\mathrm{a}}$ & -11 & -8.9 & -57 & -43 \\
\hline $\mathrm{PON}^{\mathrm{a}}$ & -16 & - & -43 & - \\
\hline $\mathrm{DOC}^{\mathrm{a}}$ & - & - & - & - \\
\hline $\mathrm{POC}^{\mathrm{a}}$ & -6.8 & - & -24 & - \\
\hline Chl $a^{b}$ & - & - & - & - \\
\hline $\mathrm{Pheo}^{\mathrm{a}}$ & 0.078 & 0.99 & 3.1 & 37 \\
\hline $\mathrm{TSP}^{\mathrm{a}}$ & - & -5.5 & - & -24 \\
\hline \multicolumn{5}{|c|}{ Only $1980 \mathrm{~s}$} \\
\hline \multicolumn{5}{|c|}{${ }^{\mathrm{b}}$ Only 1978 plus $1980 \mathrm{~s}$} \\
\hline
\end{tabular}


forms of $P, N$, and $C$ showed either a decrease or no significant trend except for $\mathrm{DNH}_{4}$, which increased slightly in Segment 4. Pheopigments increased while chlorophyll showed no significant trend. In no cases were there significant effects of week of the year on the long-term trends.

Cl concentrations increased significantly from 1971 to 1987 (Table 2) due to several years of high rainfall and high watershed flow in the 1970 s and drought and low flow in the 1980 s (Fig. 2). A trend in flow might affect the trends in other constituents besides Cl. However, there was no trend in $\mathrm{Cl}$ (or flow) during the $1980 \mathrm{~s}$ alone, and several constituents measured in the $1970 \mathrm{~s}$ and 1980 s showed about the same long-term trends when analyzed with or without data from the 1970 s, so their trends are not due to a trend in watershed flow.

The most dramatic long-term change we observed was a decrease in DON concentration by about half of its mean value over a decade (Table 2 ). However, the decrease was not uniform through time. The highest concentrations occurred from 1980 to 1982 , and the lowest in 1985 and 1986, but recently concentrations have returned to average levels (Fig. 4). Therefore, it is not clear whether the observed trend is part of a longerterm trend or whether it simply represents a coincidental sequence of interannual variations. The less dramatic trends of other constituents were similarly difficult to interpret. One thing is clear, however - the Rhode River did not become more eutrophic.

\section{Short-term response to watershed discharges}

The correlations between weekly fluctuations in flow and concentration varied throughout the year, so we

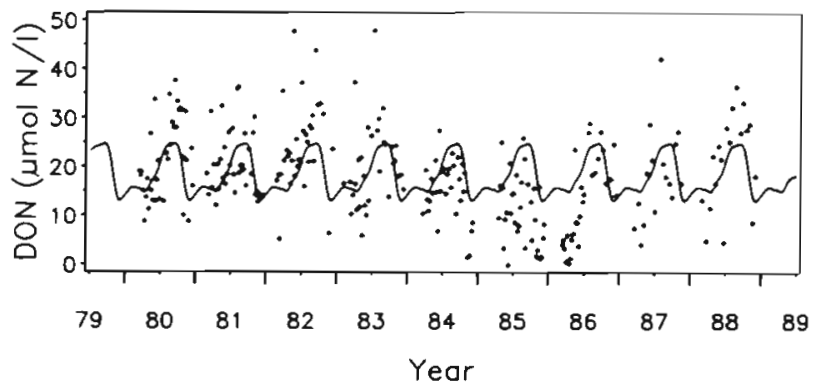

Fig. 4. Dissolved organic N (DON) concentrations in Segment 4 . Line is a smoothed fit through the mean concentrations for each week of the year based on all years of data from 1979 to 1989

analyzed data from different seasons separately, defining March-May as spring, June-August as summer, and September-November as fall. We found that dividing the sampling period into subperiods shorter than seasons reduced the statistical power too much to reveal significant correlations.

Correlations of weekly fluctuations in $\mathrm{Cl}$ concentrations with fluctuations in flow revealed the seasonally changing influences of the local and Susquehanna watersheds. $\mathrm{Cl}$ concentrations were negatively correlated with Susquehanna flow in spring, and with local flow in summer and fall (Table 3). There were lags between fluctuations in Susquehanna flow in spring and the correlated fluctuations in $\mathrm{Cl}$ concentrations, due to the transit time of water from the Conowingo Dam, where Susquehanna flow was measured, to the Rhode River, about $100 \mathrm{~km}$ away. We classified weeks so that a week of flow ended when the corresponding weekly water samples were taken. Thus, in Table 3 a lag of 0 represents a 0 to $1 \mathrm{wk}$ lag between the time the

Table 3. Correlations of weekly whitened residuals of local and Susquehanna River flow with concentrations of chloride (Cl), nitrate plus nitrite $\left(\mathrm{NO}_{3}\right)$, and chlorophyll a $(\mathrm{Chl}$ a) in Segments 4 and 5 of the Rhode River estuary. Lags are shown in parentheses. A lag of 0 represents a 0 to 1 wk lag between the time the flow took place and the time the estuary was sampled, a lag of 2 represents a 2 to $3 \mathrm{wk}$ lag, and so on. Non-significant correlations $(p>0.05)$ omitted

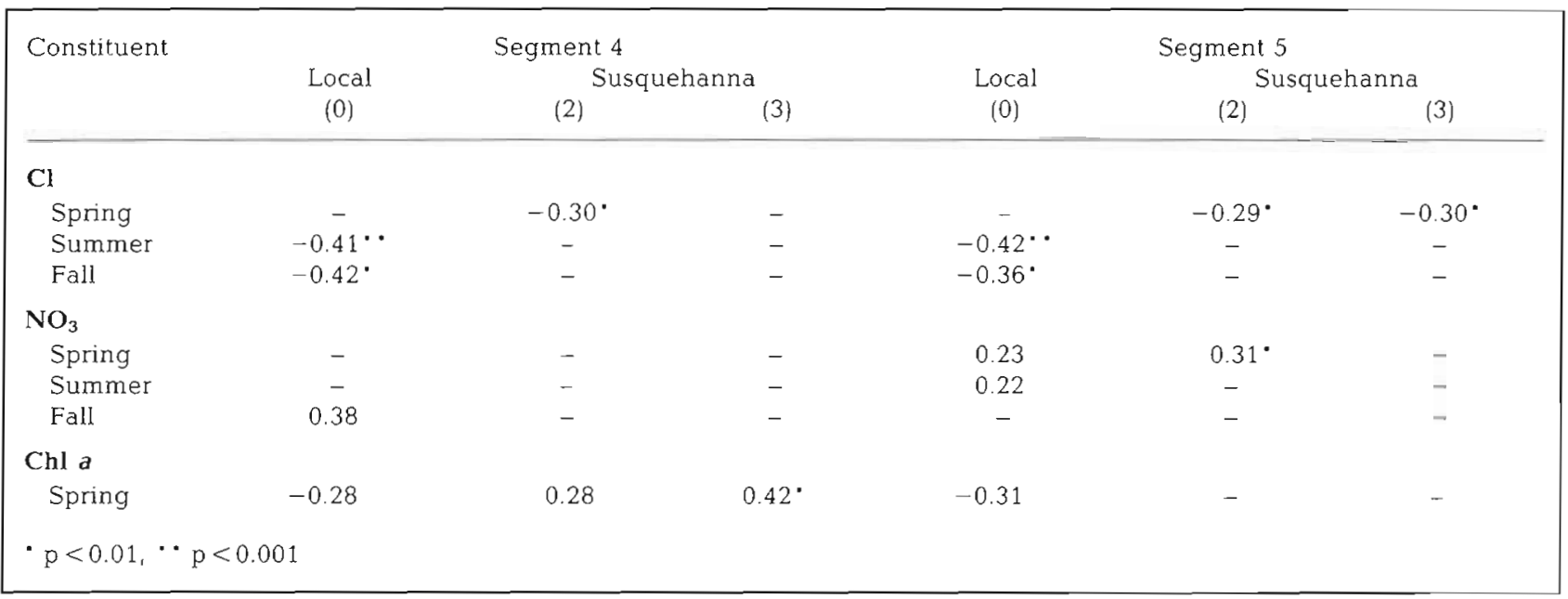


flow took place and the time the estuary was sampled, a lag of 2 represents a 2 to $3 \mathrm{wk}$ lag, and so on. The correlations suggest that water takes about 2 to 3 wk to get to Segment 4 , and about 2 to 4 wk to get to Segment 5 , from the Conowingo Dam (Table 3 ).

Since the Susquehanna and Rhode River watersheds are usually subject to similar rainfall patterns, their flow rates are correlated $(\mathrm{r}=0.34, \mathrm{p}<0.0001, \mathrm{n}=722$, whitened residuals). However, it takes at least 2 wk for water to get from the Conowingo Dam to the upper Rhode River, so the effects of the remote and local watersheds are at least 2 wk out of phase. This phase difference is enough to resolve the influences of the different watersheds because we removed correlations between consecutive weekly data points by whitening. Of course, if a local flow event had a delayed effect on the Rhode River, and if the delay were 2 to $3 \mathrm{wk}$, it might be mistaken for an effect of Susquehanna flow. However, such a delay in effect of local flow seems unlikely, because the residence time of water in the Rhode River is less than 1 wk (Han 1974, Jordan et al. 1991). Based on the $\mathrm{Cl}$ correlations, we focused on local flows at lags of 0 and $1 \mathrm{wk}$, and Susquehanna flows at lags of 2 and $3 \mathrm{wk}$, as possible correlates with the concentrations of other constituents.

Do high watershed flows lead to increased input of $\mathrm{NO}_{3}$ followed by increased phytoplankton biomass, as we have hypothesized? One would expect that high watershed discharges would elevate $\mathrm{NO}_{3}$ concentrations in the estuary because the $\mathrm{NO}_{3}$ concentrations in Susquehanna River water and in runoff from the local watershed are much higher than those in the estuary (Table 4). In fact, $\mathrm{NO}_{3}$ concentrations in Segment 5 increased as expected with increases in Susquehanna and local flow in spring, and with increases in local flow in summer (Table 3). In Segment $4, \mathrm{NO}_{3}$ concentrations increased with increases in local flow in fall. Chlorophyll concentrations also increased with increased Susquehanna flow, but only in Segment 4 in spring (Table 3). Chlorophyll decreased with increases in local flow in Segments 4 and 5 in spring (Table 3).

The strongest correlation between chlorophyll and flow was the positive correlation between Susquehanna flow at a lag of $3 \mathrm{wk}$ and chlorophyll concen-

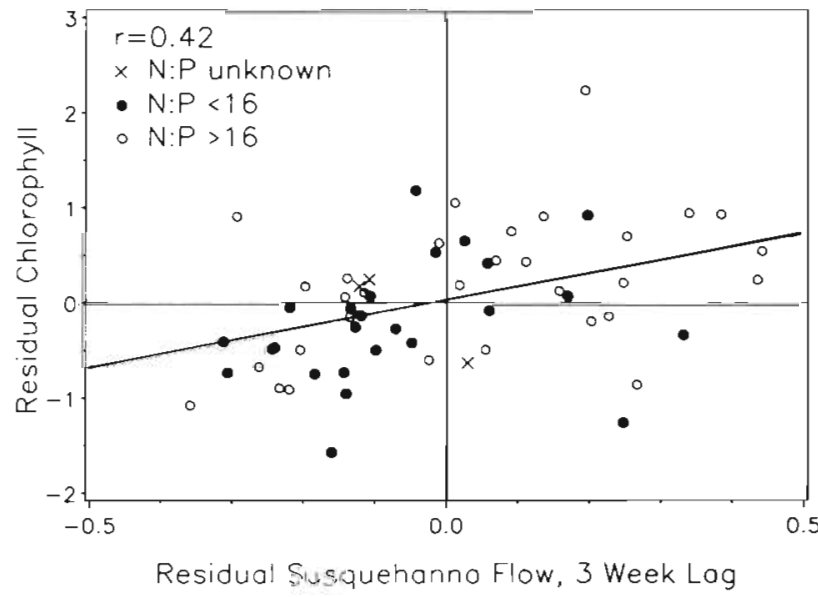

Fig. 5. Whitened residual chlorophyll concentrations in Segment 4 in spring versus whitened residual rates of Susquehanna River flow lagged by 3 wk. ( $\bullet$ Represents weeks with atomic ratios of dissolved inorganic N:P less than $16 ;(0)$ $N$ : P greater than $16 ;(\times)$ no $N$ : P data

tration in Segment 4 in spring (Table 3, Fig. 5). This suggests that increases in phytoplankton biomass occurred a few days to a week after the arrival of water from freshets of the Susquehanna. The fact that changes in $\mathrm{NO}_{3}$ concentrations did not parallel changes in chlorophyll concentrations in spring may reflect consumption of the $\mathrm{NO}_{3}$ by phytoplankton. While phytoplankton may grow in response to increases in $\mathrm{NO}_{3}$ concentration, they also reduce $\mathrm{NO}_{3}$ concentration as they grow. The weak negative correlations between local flow and chlorophyll concentrations (Table 3) may be due to flushing or low incident light from cloudy weather accompanying periods of high rainfall.

Does $\mathrm{N}$ limitation of phytoplankton growth account for the positive correlation between chlorophyll and Susquehanna flow? In Segment 4 in spring $\mathrm{DPO}_{4}$ averaged $0.26 \mu \mathrm{mol} \mathrm{l}^{-1}(0.06$ to $0.29,25$ th to 75 th percentile) while $\mathrm{DNH}_{4}$ averaged $3.0 \mu \mathrm{mol}{ }^{-1}$ (1.9 to 3.5) and $\mathrm{NO}_{3}$ averaged $8.8 \mu \mathrm{mol} 1^{-1}(0.2$ to 15$)$. These average concentrations alone do not suggest $\mathrm{N}$ limitation. However, the ratio of dissolved inorganic $N$ (DIN) to dissolved inorganic $P$ (DIP) varied widely among weeks, ranging from 0.5 to 1500 (13 to 42,25 th to 75 th percentiles).

Table 4. Mean $\mathrm{NO}_{3}$ concentrations ( $\mu \mathrm{mol}^{-1}$ ) in Susquehanna River water, runoff from the local (Rhode River) watershed, and in Segments 4 and 5 of the estuary (with 25th and 75th percentiles in parentheses). Concentrations in Susquehanna River water are from Conowingo Dam, 1984 to 1988 (R. Summers, Maryland Department of the Environment, pers. comm.). Concentrations in local watershed runoff are the average from 4 large sub-watersheds sampled with automated instruments from 1976 to 1989

\begin{tabular}{|c|c|c|c|}
\hline Area & Spring & Summer & Fall \\
\hline Susquehanna & $89 \quad(73-100)$ & $(60-79)$ & $71 \quad(44-89)$ \\
\hline Local watershed & $25 \quad(11-31)$ & $(14-36)$ & $20 \quad(7-29)$ \\
\hline Segment 4 & $8.8(0.2-15)$ & $0.24(0.00-0.29)$ & $1.3(0.14-0.71)$ \\
\hline Segment 5 & $6.8(0.3-11)$ & $0.72(0.00-0.36)$ & $1.2(0.07-1.1)$ \\
\hline
\end{tabular}


$\mathrm{N}$ is potentially limiting when the ratio is below 16 , the $\mathrm{N}$ : P ratio typical of phytoplankton biomass (Redfield 1958). Weeks with ratios above 16 had significantly (ANOVA, $p<0.05$ ) higher chlorophyll residuals than weeks with ratios below 16 (Fig. 5). This suggests that $\mathrm{N}$ limitation may indeed account for the correlation of chlorophyll concentration and Susquehanna flow. However, it should be noted that even when DIN : DIP is above 16 it is still possible that other factors besides DIN or DIP can limit phytoplankton growth.

Another possible limiting factor is water temperature. Accordingly, we analyzed the correlation between fluctuations in chlorophyll concentration and fluctuations in temperature after deseasonalizing and whitening the data. It was hard to separate the effect of temperature from that of flow because unseasonably cool weather coincides with periods of rainfall. Thus, the deseasonalized and whitened residuals of temperature were negatively correlated with the residuals of watershed flow. The residuals of temperature in Segment 4 in spring were also negatively correlated with the chlorophyll residuals with a lag of $3 \mathrm{wk}$. However, this is most likely a reflection of the relationship between temperature and Susquehanna flow. It seems unlikely that temperature fluctuations per se could effect chlorophyll after a lag of $3 \mathrm{wk}$.

\section{Seasonal-scale response to watershed discharges}

The correlations of weekly changes in flow and concentration explain no more than $20 \%$ of the total variance of the whitened residuals (Table 3, Fig. 5), but these correlations reflect only short-term responses to flow events. The serial correlation of the weekly data suggests that correlations between flow and concentration may also exist at multi-week time scales. For example, in some years chlorophyll concentrations showed persistent departures from the seasonal averages. The most notable was 1981, with consistently low concentrations (Fig. 6). This period coincided with a long period of consistently low Susquehanna flow in late 1980 and early 1981 (Fig. 2). To analyze such multiweek patterns we tested correlations of seasonally aggregated data, shifting the definition of season back by $2 \mathrm{wk}$ for Susquehanna flow to compensate for the transit time from Conowingo Dam.

Aggregating the data by season focused on longertime-scale responses of the estuary, but made it harder to separate the effects of local and Susquehanna flow because the aggregated flows of the 2 watersheds are correlated $(\mathrm{r}=0.51, \mathrm{p}<0.0001, \mathrm{n}=56)$. However, in some cases the flows differed enough to distinguish the effects of the different watersheds. For example, in spring, $\mathrm{Cl}$ concentrations were negatively correlated

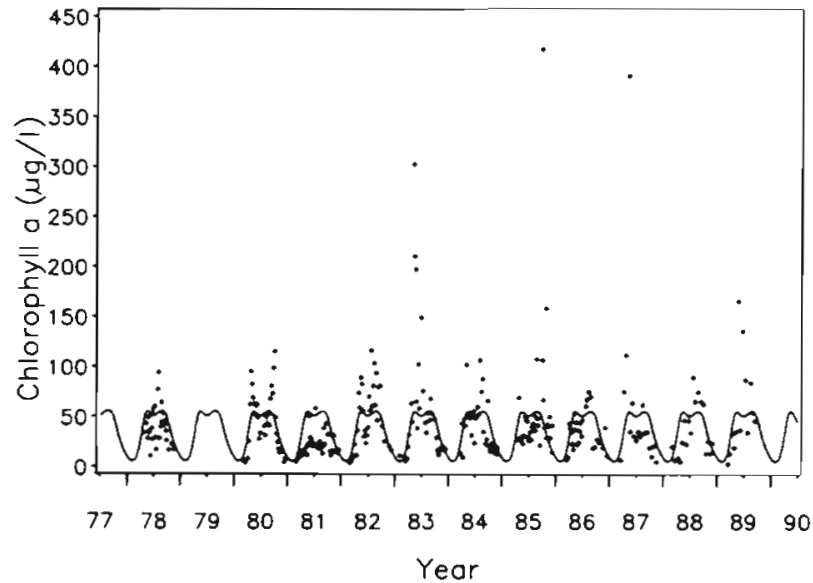

Fig. 6. Chlorophyll a concentrations in Segment 4. Line is a smoothed fit through the mean concentrations for each week of the year based on all the years of data from 1977 to 1990

with Susquehanna flow, but not significantly correlated with local flow (Table 5). However, in summer, $\mathrm{Cl}$ was negatively correlated with both Susquehanna and local flow. We also examined correlations of summer and fall concentrations with flows of the previous spring, since most of the yearly flow occurs in spring. In summer, $\mathrm{Cl}$ concentrations were correlated with flows in the previous spring (Table 5). In fall, $\mathrm{Cl}$ concentrations in Segment 5 were correlated with fall flows from both local and Susquehanna watersheds, while $\mathrm{Cl}$ concentrations

Table 5. Correlations of seasonally aggregated residuals of local and Susquehanna (Susq.) flows with concentrations of chloride $(\mathrm{Cl})$, nitrate plus nitrite $\left(\mathrm{NO}_{3}\right)$, and chlorophyll a (Chl a). Correlations are shown for concentrations (Conc.) with flow in the same season, and with flow in the previous spring. Time frame of season for Susquehanna flow is shifted back 2 wk. Non-significant correlations $(p>0.05)$ omitted

\begin{tabular}{|c|c|c|c|c|c|}
\hline \multicolumn{2}{|c|}{ Season } & \multicolumn{2}{|c|}{ Segment 4} & \multicolumn{2}{|c|}{ Segment 5} \\
\hline Conc. & Flow & Local & Susq. & Local & Susq. \\
\hline \multicolumn{6}{|l|}{$\mathrm{Cl}$} \\
\hline Spring & Spring & - & $-0.86 \cdots$ & - & $-0.78^{\circ}$ \\
\hline Summer & Summer & -0.71 & $-0.81^{\circ}$ & $-0.71^{\circ}$ & $-0.81^{\circ}$ \\
\hline Summer & Spring & -0.67 & $-0.84^{\prime}$ & -0.66 & $-0.77^{\circ}$ \\
\hline Fall & Fall & - & - & -0.62 & -0.64 \\
\hline Fall & Spring & - & -0.67 & - & - \\
\hline \multicolumn{6}{|l|}{$\mathrm{NO}_{3}$} \\
\hline Spring & Spring & - & - & 0.70 & 0.67 \\
\hline Summer & Summer & - & - & - & - \\
\hline Summer & Spring & - & - & - & -0.57 \\
\hline Fall & Fall & - & $0.80^{\circ}$ & - & $0.75^{\circ}$ \\
\hline \multicolumn{6}{|l|}{ Chl a } \\
\hline Spring & Spring & - & 0.73 & - & - \\
\hline Summer & Summer & - & - & - & - \\
\hline Summer & Spring & - & 0.62 & - & 0.64 \\
\hline$\cdot p<0.01$, & $\cdots p<0$ & & & & \\
\hline
\end{tabular}


in Segment 4 were correlated with spring flow from the Susquehanna.

The fall data from Segment 4 illustrate the importance of examining different time scales. On a weekly time scale, fall $\mathrm{Cl}$ concentrations correlated with local flow (Table 3), but on a seasonal time scale they correlated with Susquehanna flows of the previous spring (Table 5). In other words, the input of fresh water from the Susquehanna in the spring sets a baseline concentration that persists into the fall, while weekly fluctuations in local flow generate immediate fluctuations in concentration away from the baseline.

Correlations between flows and concentrations of $\mathrm{NO}_{3}$ and chlorophyll at the seasonal time scale show both similarities and differences to correlations at the weekly time scale. In spring, the different time scales have about the same pattern, with $\mathrm{NO}_{3}$ in Segment 5 correlating with flows from both local and Susquehanna watersheds, and chlorophyll in Segment 4 correlating with Susquehanna flow (Tables 3 \& 5). However, in summer, chlorophyll correlated with spring Susquehanna flow at the seasonal time scale (Table 5), while there were no significant correlations at the weekly time scale. $\mathrm{NO}_{3}$ concentrations in Segment 5 in summer show a perplexing but weak negative correlation with spring Susquehanna flows at the seasonal time scale. In fall, $\mathrm{NO}_{3}$ concentrations in Segment 4 were positively correlated with Susquehanna flow at the seasonal scale (Table 5), but with local flow at the weekly scale (Table 3).

At the seasonal time scale, spring chlorophyll concentrations in Segment 4 were clearly related to Susquehanna flow rather than local flow. Spring chlorophyll concentrations were lowest in 1981 and 1988, when Susquehanna flow was lowest, but spring chlorophyll concentrations were intermediate in 1985 and 1986 when local flow was lowest (Fig. 7). In spring 1987 there were unusually high chlorophyll concentrations, considering the intermediate Susquehanna flow (Fig. 7). These chlorophyll data were highly influenced by a single observation of $390 \mu \mathrm{g} \mathrm{l}^{-1}$ during a bloom on 6 May (Fig. 6), 3 to $4 \mathrm{wk}$ after a period of high Susquehanna flow from 6 to 11 April. The time lag between the flow event and the bloom was consistent with the correlations at the weekly time scale (Table 3 ). Thus, although spring 1987 appears as an outlier in the seasonal time scale correlation (Fig. 7), the bloom was probably related to a brief period of high Susquehanna flow occurring in an otherwise dry spring.

The correlation between summer chlorophyll and spring Susquehanna flow in Segment 4 was strongly influenced by the data from a single year, 1981 (Fig. 8). However, the same correlation for Segment 5 seemed to be part of a general pattern, with 1988 standing out as an exception (Fig. 8).
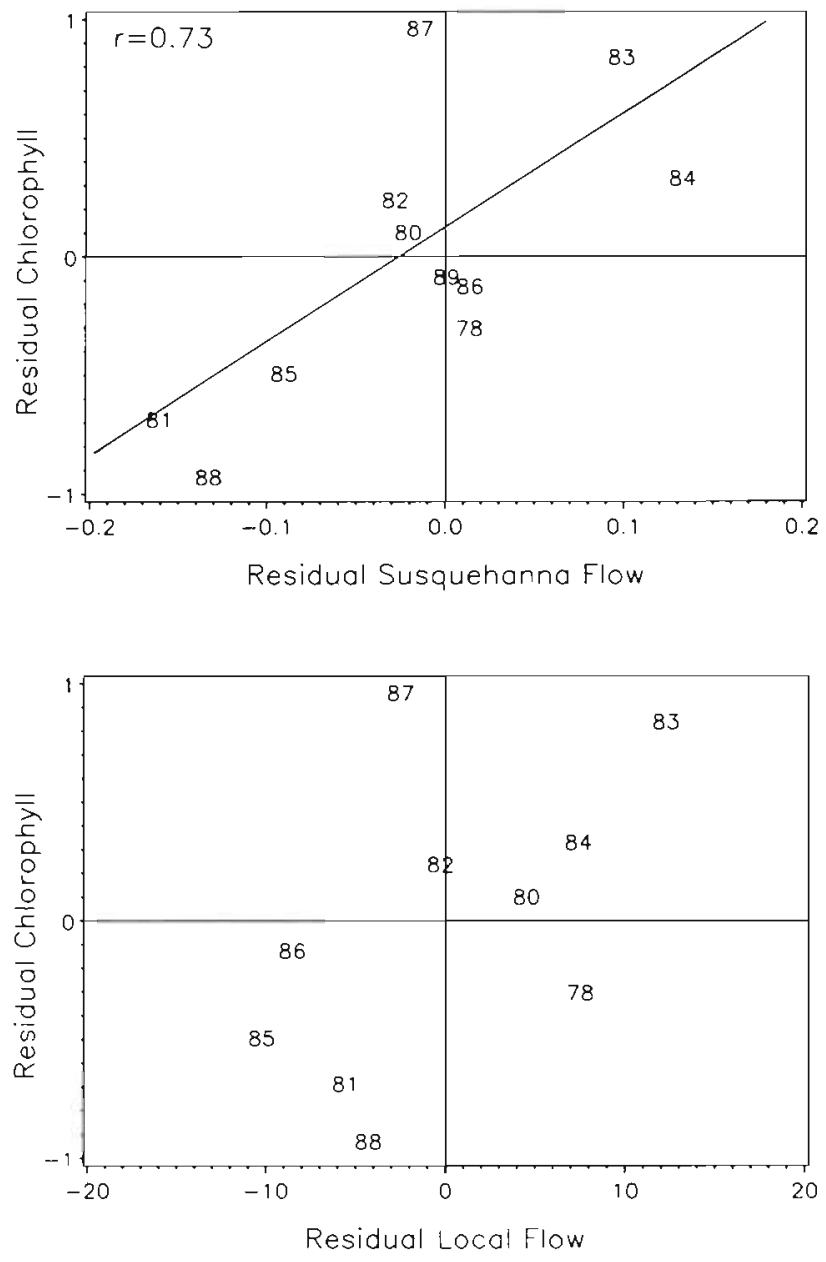

Fig. 7. Seasonally aggregated residuals of chlorophyll concentration in Segment 4 in spring versus the seasonally aggregated residuals of Susquehanna River flow (top) and local flow (bottom) in spring. Numbers plotted for data points indicate the year Line fit by linear regression. Data from 1985 and 1978 were omitted from regression and correlation analyses because only 2 out of the 3 months of the season were sampled

\section{DISCUSSION}

The influence of Susquehanna flow on water quality in the Rhode River suggests that eutrophication of midChesapeake Bay would be paralleled by eutrophication of the Rhode River. Long-term data indicate increases in concentrations of $\mathrm{DPO}_{4}$ and possibly chlorophyll in the upper and middle Chesapeake Bay prior to 1980 (D'Elia 1982). Similarly, the Patuxent River, a subestuary south of the Rhode River, has increased in $\mathrm{DPO}_{4}$, chlorophyll, and $\mathrm{NO}_{3}$ content (D'Elia 1982). However, our data do not show increasing eutrophication in the Rhode River. There were no long-term trends in chlorophyll concentrations, and the small increases in $\mathrm{DNH}_{4}$ were more than offset by large decreases in organic $N$ (Table 2). Although Correll 

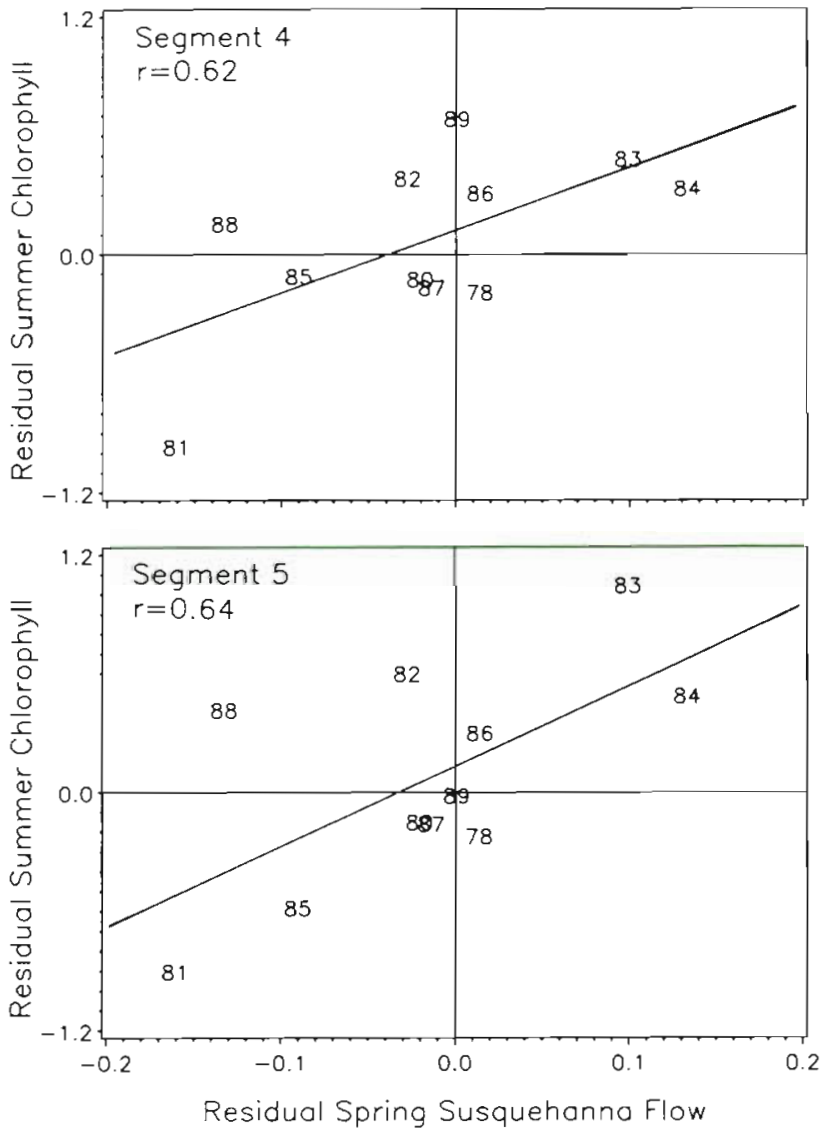

Fig. 8. Seasonally aggregated residuals of chlorophyll concentration in summer in Segments 4 and 5 versus the seasonally aggregated residuals of Susquehanna River flow in the previous spring. Numbers plotted for data points indicate the year Lines fit by linear regression

(1981b) observed increases in total P in the Rhode River during the 1970s, we observed a reversal of this trend in the $1980 \mathrm{~s}$, with overall decreases in most forms of $P$ throughout the 1970s and 1980s (Table 2).

Perhaps the eutrophication of upper Chesapeake Bay has ceased in recent years or slowed sufficiently so that it has not caused increasing eutrophication of the Rhode River. Recent data on inputs from the Susquehanna River support this conclusion. Although total $\mathrm{N}$ inputs from the Susquehanna increased from 1978 to 1983, they showed no trend from 1984 to 1990 , and total P inputs showed no trend between 1978 and 1990 (R. Summers, Maryland Department of the Environment, pers. comm.). N inputs from the Susquehanna result mainly from fertilizer applications (Clark et al. 1974). Applications of $\mathrm{N}$ fertilizers in the Chesapeake watershed increased sharply in the 1960 s, stayed about constant in the 1970s, and declined in the 1980s (Hargett \& Berry 1983, Berry \& Hargett 1989). Similarly, local inputs of nutrients from the Rhode River watershed, originating mainly from fertilizer applica- tions to croplands (Jordan et al. 1986), have not changed much (D. E. Weller unpubl.), possibly because the area of cropland in the watershed has remained relatively constant in the last 2 decades. In another coastal-plain watershed, increases in farming have caused increases in $\mathrm{NO}_{3}, \mathrm{DPO}_{4}$, and turbidity in estuarine receiving waters (Ustach et al. 1986).

The largest and most consistent trend in the Rhode River was a decrease in DON (Table 2, Fig. 4). There was also a decrease in PON (Table 2). These trends may reflect a similar decreasing trend in the discharge of total organic $N$ from the watershed (D. E. Weller unpubl.), but we do not know the cause of the decreases in organic $N$ discharges. Much of the suspended PON and POP in the estuary is in phytoplankton biomass (Jordan et al. 1991), yet the decreasing trends in PON and POP were not accompanied by longterm decreases in chlorophyll (Table 2).

Short-term fluctuations in chlorophyll concentration were in some cases positively correlated with fluctuations in Susquehanna flow. Cory \& Dressler (1981) also concluded that phytoplankton productivity in Segment 4 of the Rhode River was higher during years with higher flow, because salinity was negatively correlated with the magnitude of diel changes in oxygen concentrations in the summers and falls between 1970 and 1978. Phytoplankton biomass in the main stem of central Chesapeake Bay may also increase with increases in Susquehanna flow (Tyler \& Seliger 1978, Boynton et al. 1982, Malone et al. 1988). However, the patterns of chlorophyll concentrations in the Rhode River are not simply due to import of phytoplankton from adjacent Chesapeake Bay. In fact, there is a net export of chlorophyll from the Rhode River upstream of Segment 4 (Jordan et al. 1991), and probably from the rest of the Rhode River, judging from the fact that chlorophyll concentrations in this river are usually higher than those in Chesapeake Bay (Seliger \& Loftus 1974)

It is difficult to distinguish effects on phytoplankton due to inputs of nutrients from those due to input of freshwater, because nutrient and freshwater inputs are very highly correlated. Changes in freshwater inflow per se could effect phytoplankton biomass by altering flow patterns or stratification in the estuary (e.g. Tyler 1986). However, the Rhode River is a well-mixed estuary, so stratification and estuarine countercurrents within the Rhode River are probably not important factors in controlling production or biomass. Also, effects of flushing can only explain negative correlations between flow and chlorophyll concentrations, and we observed positive correlations as well. Nevertheless, phytoplankton in the Rhode River are sometimes affected by circulation patterns in Chesapeake Bay. For example, in spring 1987 there was a large bloom of the dinoflagellate Prorocentrum marieae-lebouriae which 
began in Chesapeake Bay and moved into the Rhode River (C. Gallegos unpubl.). This bloom produced the highest spring chlorophyll levels we have observed (Fig. 6). Such blooms are promoted by upstream transport of $P$. marieae-lebouriae in deep waters of Chesapeake Bay, followed by upwelling of these waters in circulation patterns driven by high river flows (Tyler \& Seliger 1978). Interestingly, this particular bloom occurred in a year when Susquehanna flows were below the threshold suggested by Tyler \& Seliger (1978) for bloom formation. However, it did occur about 3 wk after a high-flow event, as would be expected from our correlation analysis.

Our data suggest that the response of photosynthesis to changes in Susquehanna flow is due to changes in $\mathrm{NO}_{3}$ influx. Similarly, Boynton et al. (1982) and Malone et al. (1988) suggest that production and biomass of phytoplankton in mesohaline Chesapeake Bay respond to changes in $\mathrm{NO}_{3}$ influx from the Susquehanna. Flint et al. (1986) also attribute changes in productivity in a Gulf Coast estuary to changes in fluvial $\mathrm{N}$ inputs.

In the Rhode River, $\mathrm{NO}_{3}$ concentrations sometimes correlated with Susquehanna flow, but not at the same times that chlorophyll concentrations did. This would be expected if the phytoplankton deplete the $\mathrm{NO}_{3}$ as they grow in response to increased $\mathrm{NO}_{3}$ loading. Indeed, most of the $\mathrm{NO}_{3}$ entering the Rhode River from its local watershed is consumed upstream of Segment 4 and, judging from the $\mathrm{NO}_{3}$ concentration gradient, the Rhode River imports and consumes $\mathrm{NO}_{3}$ from adjacent Chesapeake Bay as well (Jordan et al. 1991). In summer the concentration of $\mathrm{NO}_{3}$ is low, sometimes undetectable, and chlorophyll concentrations may instead depend on $\mathrm{DNH}_{4}$ release from organic matter produced in spring, when production is supported by $\mathrm{NO}_{3}$ from the spring freshet, as suggested by Malone et al. (1988) for mesohaline Chesapeake Bay and Bennett et al. (1986) for the tidal Potomac river.

Variation of the DIN:DIP ratio supports the hypothesis that $\mathrm{N}$ limitation accounts for the correlation between chlorophyll and flow in the Rhode River. Although the DIN : DIP ratio is highest when $\mathrm{NO}_{3}$ concentrations are elevated by the spring freshet (Jordan et al. 1991), the ratio is frequently below 16 in spring, and at such times chlorophyll concentrations tend to be low (Fig. 5). Increases in Susquehanna flow can raise DIN concentrations in the Rhode River because runoff from the Susquehanna watershed is rich in $\mathrm{NO}_{3}$ (Table 4), mostly from fertilizer applications (Clark et al. 1974, Correll 1987). However, increases in Susquehanna flow do not increase DIP concentrations, since the main source of DIP in the Rhode River is release of $\mathrm{DPO}_{4}$ from sediments of the upper estuary (Jordan et al. 1991).

At the weekly time scale, pulses of $\mathrm{NO}_{3}$-rich water injected during periods of high Susquehanna flow in spring apparently promote immediate blooms. Later, the $\mathrm{N}$ assimilated during these blooms is gradually regenerated as $\mathrm{DNH}_{4}$, which supports the phytoplankton community in summer over the seasonal time scale. Correlations of chlorophyll concentrations with Susquehanna flow suggest that eutrophication of the upper Chesapeake Bay would induce eutrophication of the Rhode River. The fact that the Rhode River has not become more eutrophic in the last 10 to 18 yr raises the possibility that eutrophication of upper Chesapeake Bay has likewise ceased in recent years.

Acknowledgements. This research was supported by the Smithsonian Environmental Sciences Program; by NSF grants BSR 79-11563, BSR 82-07212, BSR 83-16948, and BSR 8615902 ; by EPA grant R80453601; and by a series of awards under the NSF-RANN program. Dr C. Gallegos provided helpful discussion of an early draft.

\section{LITERATURE CITED}

APHA (American Public Health Association) (1976). Standard methods for the examination of water and wastewater 14 th edn. APHA, Washington, D. C.

Bennett, J. P., Woodward, J. W., Shultz, D. J. (1986). Effect of discharge on the chlorophyll a distribution in the tidallyinfluenced Potomac River. Estuaries 9: 250-260

Berry, J. T., Hargett, N. L. (1989). 1988 Fertilizer Summary Data Bulletin Y-209. National Fertilizer Development Center Tennessee Valley Authority, Muscle Shoals, Alabama

Box, G. E. P., Jenkins, G. M. (1976). Time series analysis, forecasting and control, revised edn. Holden-Day, San Francisco

Boynton, W. R., Kemp, W. M., Keefe, C. W. (1982). A comparative analysis of nutrients and other factors influencing estuarine phytoplankton production. In: Kennedy, V.S. (ed.) Estuarine comparisons. Academic Press, New York, p. 69-90

Brush, G. S. (1984). Stratigraphic evidence of eutrophication in an estuary. Wat. Resour. Res. 20: 531-541

Carpenter, J. H., Pritchard, D. W., Whaley, R. C. (1969). Observations of eutrophication and nutrient cycles in some coastal plain estuaries. In: Eutrophication: causes, consequences, correctives - proceedings of a symposium. National Academy of Sciences, Washington, D.C. p. $210-221$

Clark, L. J., Guide, V., Pfeiffer, T H. (1974). Summary and conclusions, nutrient transport and accountability in the lower Susquehanna River basin. Technical Rep. 60. U.S Environmental Protection Agency, Washington, D.C.

Correll, D. L. (1977). An overview of the Rhode River watershed program. In: Correll, D. L. (ed.) Watershed research in eastern North America. Smithsonian Institution Press, Washington, D.C., p. 105-124

Correll, D. L. (1981a). Nutrient mass balances for the watershed, headwaters intertidal zone, and basin of the Rhode River estuary. Limnol. Oceanogr. 26: 1142-1149

Correll, D. L. (1981b). Eutrophication trends in the water quality of the Rhode River (1971-1978). In: Neilson, B. J., Cronin, L. E. (eds.) Estuaries and nutrients. The Humana Press, Clifton, p. 425-435

Correll, D. L. (1987). Nutrients in Chesapeake Bay. In: Majum dar, S. K., Hall, L. W. Jr, Austin, H. M. (eds.) Contaminant problems and management of living Chesapeake Bay 
resources. The Pennsylvania Academy of Science, Phillipsburg, p. 298-320

Correll, D. L., Miklas, J. J. (1975). Phosphorus cycling in a Maryland deciduous forest subjected to various levels of mineral nutrient loading. In: Howell, F. G., Gentry, J. B., Smith, M. H. (eds.) Mineral cycling in southeastern ecosystems. ERDA Symposium Series, ERDA, Washington, D.C., p. 642-657

Cory, R. L., Dressler, P. V. (1981). Diel oxygen variations in the Rhode River Estuary, Maryland, 1970-1978. U.S. Geological Survey Water Resources Investigations Rep. 81-10, Washington, D.C.

D'Elia, C. F. (1982). Nutrient enrichment of concentration: an historical perspective. In: Macalaster, E. G., Barker, D. A., Kasper, M. (eds.) Chesapeake Bay Program technical studies: a synthesis. U.S. Environmental Protection Agency, Washington, D.C., p. 45-102

Dobbs, R. A., Williams, R. T. (1963). Elimination of chloride interference in the chemical oxygen demand test. Analyt. Chem. 35: 1064-1067

Flint, R. W., Powell, G. L., Kalke, R. D. (1986). Ecological effects from the balance between new and recycled nitrogen in Texas coastal waters. Estuaries 9: 284-294

Goldman, C. R., Jassby, A., Powell, T (1989). Interannual fluctuations in primary production: meteorological forcing at two subalpine lakes. Limnol. Oceanogr. $34: 310-323$

Gandy, A. F., Ramanthan, M. (1964). A colorimetric method for determining chemical oxygen demand. J. Wat. Pollut. Control Fed. 36: 1479-1487

Han, G. C. (1974). Salt balance and exchange in the Rhode River, a tributary embayment to the Chesapeake Bay. $\mathrm{Ph} . \mathrm{D}$. thesis. The Johns Hopkins University, Baltimore

Hargett, N. L., Berry, J. T. (1983). 1982 Fertilizer Summary Data. Bulletin Y-180. National Fertilizer Development Center, Tennessee Valley Authority, Muscle Shoals, Alabama

Hecky, R. E., Kilham, P. (1988). Nutrient limitation of phytoplankton in freshwater and marine environments: a review of recent evidence on the effects of enrichment. Limnol. Oceanogr. 33: 796-822

Hirsch, R. M., Slack, J. R., Smith, R. A. (1982). Techniques of trend analysis for monthly water quality data. Wat. Resour. Res. 18: 107-121

Huffman, E. W. D. Jr (1977). Performance of a new automatic carbon dioxide coulometer. Microchen. J. 22: 567-573

Hurlburt, S. H. (1984). Pseudoreplication and the design of ecological field experiments. Ecol. Monogr. 54: 187-211

Jaworski, N. A. (1981). Sources of nutrients and the scale of eutrophication problems in estuaries. In: Nielson, B. J., Conrin, L. E. (eds.) Estuaries and nutrients. Humana Press, Clifton, p. 83-110

Jeffrey, S. W., Humphrey, G. F. (1975). New spectrophotometric equations for determining chlorophyll $a, b, c_{1}$, and $c_{2}$ in higher plants, algae and natural phytoplankton. Biochem. Physiol. Pfl. 167: 191-194

Jordan, T E., Correll, D. L., Peterjohn, W T., Weller, D. E (1986). Nutrient flux in a landscape: the Rhode River Watershed and receiving waters. In: Correll, D. L. (ed.) Watershed research perspectives. Smithsonian Press, Washington, D.C., p. 57-75

Jordan, T E., Correll, D. L., Miklas, J. J., Weller, D. E. (1991). Nutrient and chlorophyll at the interface of a watershed and an estuary. Limnol. Oceanogr 36: 251-267

Keeney, D. R., Nelson, D. W (1982). Nitrogen - Inorganic forms. In: Page, A. L., Miller, R. H., Keeney, D. R. (eds.)
Methods of soil analysis: Part 2, 2nd edn. American Society of Agronomy, Inc., Soil Science Society of America, Inc., Madison, p. 643-698

Kemp, W. M., Boynton, W. R., Twilley, R. R., Stevenson, J. C., Means, J. C. (1983). The decline of submerged vascular plants in the upper Chesapeake Bay: summary of results concerning possible causes. J. mar. technol. Soc. 17: 78-89

King, E. J. (1932). The colorimetric determination of phosphorus. Biochem. J. 26: 292-297

Maciolek, J. A. (1962). Limnological organic analyses by quantitative dichromate oxidation. U.S. Fish and Wildlife Services Publication, Washington, D.C.

Malone, T. C., Crocker, L. H., Pike, S. E., Wendler, B. W. (1988). Influences of river flow on the dynamics of phytoplankton production in a partially stratified estuary. Mar. Ecol. Prog. Ser. 48: 235-249

Martin, D. F. (1972). Marine chemistry, Vol. 1. Dekker, New York

Officer, C. B., Biggs, R. B., Taft, J. L., Cronin, L. E., Tyler, M. A., Boynton, W. R. (1984). Chesapeake Bay anoxia: origin, development, and significance. Science 223: 22-27

Price, K. S., Flemer, D. A., Taft, J. L., Mackiernan, G. B. (1985) Nutrient enrichment of Chesapeake Bay and its impact on the habitat of striped bass: a speculative hypothesis. Trans. Am. Fish. Soc. 114: 97-106

Redfield, A. C. (1958). The biological control of chemical factors in the environment. Am. Scient. 46: 205-221

SAS Institute Inc. (1984). SAS/ETS user's guide, version 5 edn. SAS Institute, Inc., Cary, North Carolina

Schubel, J. R. Pritchard, D. W (1986). Responses of upper Chesapeake Bay to variations in discharge of the Susquehanna River. Estuaries 9: 236-249

Seliger, H. H., Loftus, M. E. (1974). Growth and dissipation of phytoplankton in Chesapeake Bay. II. A statistical analysis of phytoplankton standing crops in the Rhode and West Rivers and an adjacent section of the Chesapeake Bay. Chesapeake Sci. 15: 185-204

Shoaf, W. T. Lium, B. W. (1976). Improved extraction of chlorophyll $a$ and $b$ from algae using dimethyl sulfoxide. Limnol. Oceanogr. 21: 926-928

Sokal, R. R., Rohlf, F. J. (1981). Biometry, 2nd edn. W. H. Freeman \& Company, San Francisco

Strickland, J. D. H., Parsons, T R. (1972). A practical handbook of seawater analysis, 2nd edn. Bull. Fish. Res. Bd Can. 167: 1-310

Technicon (1978). Method 118-71 W/B. Technicon Industrial Systems. Tarrytown, New York

Technicon (1983). Method 696-82 W. Technicon Industrial Systems. Tarrytown, New York

Tyler, M. A. (1986). Flow-induced variation in transport and deposition pathways in the concentration: the effect on phytoplankton dominance and anoxia. In: Wolfe, D. A. (ed.) Estuarine variability. Academic Press, New York, p. $161-175$

Tyler, M. A., Seliger, H. H. (1978). Annual subsurface transport of a red tide dinoflagellate to its bloom area: water circulation patterns and organism distribution in the Chesapeake Bay. Limnol. Oceanogr 23: 227-246

Ustach, J. F., Kirby-Smith, W W., Barber, R. T (1986). Effect of watershed modification on a small coastal plain estuary. In: Wolfe, D. A. (ed.) Estuarine variability. Academic Press, New York, p. 177-192

van Belle, G., Hughes, J. P. (1984). Nonparametric tests for trend in water quality. Wat. Resour Res. 20:127-136 